\title{
Od mitu do relatywizmu czyli mikro- i makroanaliza w metodologii badań pragmatycznych
}

\section{Piotr Cap}

Uniwersytet Łódzki

\section{Wstęp}

W niniejszym tekście dowodzę, że analiza pragmatyczna ma charakter $\mathrm{n}$ a $\mathrm{t} \mathrm{u}$ r a $1 \mathrm{n}$ i e i n d u k c y j n y, a tradycyjne parametry analizy (deiksa, presupozycja, implikatura oraz akt mowy) dostarczają opisów, które wiążą się ze sobą w sposób (i) wzajemnie komplementarny, (ii) hierarchiczny, wykraczając tym samym poza wyjściowy poziom w y r a ż e n i a (poziom 'mikro') i nieuchronnie (a także niezwłocznie) zmierzając w kierunku makroanalizy t e k s t u/d y s k r s u ${ }^{1}$ - nieraz kosztem utraconych w ten sposób bądź też zignorowanych obserwacji poziomu mikro. Makropragmatyczna hierarchia, wynikająca z samoistnego łączenia się indywidualnych kategorii opisu na rzecz kategorii nadrzędnej (np. makroaktu mowy), ma charakter potencjalnie nieskończony i, co za tym idzie, nie zawsze doprecyzowany względem pola badawczego (określonej części lub całości danego tekstu/dyskursu), do którego miałaby się odnosić. Mamy więc do czynienia z sytuacją, w której dokładny opis na poziomie mikro jest de facto wykluczony przez 'pęd' analizy 'w górę', zaś opis na poziomie makro często nosi ryzyko względności.

Przyczyną takiego stanu rzeczy jest, moim zdaniem, charakterystyka teorii aktów mowy, modelu, który od czasów Johna L. Austina i Johna R. Searle'a przyjęto za podstawowy aparat porządkujący analizy pragmatycznej. Jest to charakterystyka metodologicznie dwukierunkowa. $Z$ jednej strony kompleksowy opis aktu mowy (tj. opis zbiorczy intencji, formy językowej, efektu perlokucyjnego) w sposób naturalny zawiera w sobie rozważania dotyczące pojęć podrzędnych, bardziej wymiernych pod względem formy językowej (np. deiksa) lub też

\footnotetext{
${ }^{1}$ Prezentację długoletniej debaty nad rozróżnieniem pojęć „tekst”/,,dyskurs” uważam za nieistotną z punktu widzenia celów niniejszego tekstu. Zainteresowanego czytelnika odsyłam do znakomitej pracy przeglądowej autorstwa Davida Howartha (2000).
} 
o stosunkowo ograniczonym potencjale wyjaśniającym (np. presupozycja, jako pojęcie wpisane głównie w rzeczywistość nadawcy). Z drugiej strony, opis aktu mowy nieuchronnie wymyka się ramom pojedynczego wyrażenia i przywołuje kwestie intencjonalności oraz efektu perlokucyjnego na poziomie tekstu/ dyskursu. W pierwszym przypadku dochodzi do zaniku mikroanalizy pojęć składowych per se na rzecz analizy zbiorczej, co może skutkować pominięciem interesujących zjawisk fragmentarycznych, dotyczących czy to 'samej formy', 'samej intencji', czy też 'samego efektu'. W drugim przypadku mamy do czynienia ze zmniejszającym się stopniem systematyzacji analizy na kolejnych, coraz wyższych jej poziomach. Choć pojęcie aktu mowy pomaga w usystematyzowaniu i uogólnieniu analizy na poziomie danego, pojedynczego wypowiedzenia, należy wskazać, że potencjał ów jest znacznie mniejszy na poziomie tekstu/dyskursu. Powodem tego jest względność pojęcia intencji wyrażanej aktem mowy, która rośnie wraz z każdym kolejnym szczeblem prowadzonej analizy.

\section{Dyskusja: poziom mikropragmatyczny (wyrażenia)}

Teoria aktów mowy (Austin 1962; Searle 1975 oraz bardzo liczne późniejsze modyfikacje, por. przegląd tychże w: Tsohatzidis, red. 1994; Post 2001; Horn, Ward 2004; Kalisz 2006; Huang 2007 itp.) należy do najczęściej dyskutowanych zagadnień pragmatyki językowej. Jej popularność wynika w dużym stopniu z faktu, iż nie sposób analizować akty mowy bez jednoczesnego, choćby pośredniego odniesienia do innych pojęć pragmatycznych, takich jak: deiksa, presupozycja czy implikatura. Dodatkowo, analizy aktów mowy często lokują je - mniej lub bardziej świadomie - w pozycji nadrzędnej w stosunku do innych pojęć. Na poziomie 'mikropragmatycznym' (czyli zamykającym się w obrębie intencji i efektu konkretnego wyrażenia; por. Mey 2001) takie podejście ma swoje uzasadnienie. Rozważmy następujący przykład:

(1) Wy sobie nie myślcie, że każdy musi zaliczyć te zajęcia.

Załóżmy, że analityk ma dostęp do następujących danych kontekstowych (a)-(f) i (jedynie) na ich podstawie określa intencję ('siłę illokucyjną'), a także oczekiwany efekt ('perlokucyjny') wyrażenia (1):

a) nadawcą (1) jest nauczyciel akademicki znany z liberalnego podejścia do rozliczania studentów z nabywanej wiedzy; 
b) (1) wypowiedziane jest w trakcie zajęć o charakterze wykładu;

c) zajęcia te są obowiązkowe, ale wykładowca rzadko sprawdza listę obecności;

d) (zapewne m.in. w związku z (c)) na zajęcia regularnie uczęszcza jedna trzecia z zapisanych na nie studentów;

e) (1) zostało wypowiedziane bezpośrednio po tym, jak trójka studentów przyszła na wykład z 20-minutowym opóźnieniem.

f) sytuacja opisana w e. ma miejsce po raz pierwszy.

Spekulacje na temat aktu mowy (rozumianego w kategoriach pochodnej treści, intencji i możliwego/oczekiwanego efektu), zawartego w (1), obracają się niejako nieuchronnie wśród wymienionych wcześniej pojęć 'podrzędnych' deiksy, presupozycji i implikatury. Analityk ocenia, w jaki sposób treść wyrażenia przekazana jest na poziomie leksykalnym i strukturalnym (analiza pozapragmatyczna), do jakich elementów kontekstu wyrażenie się odwołuje i jak te elementy są leksykalizowane (obszar 'roboczy' deiksy), jakie założenia mogły zostać poczynione przez nadawcę, w świetle danych (a)-(f), zanim (1) zostało wypowiedziane (obszar presupozycji), oraz jaki efekt może wywołać to wyrażenie (obszar implikatury) - w kontekście wszystkich do tego momentu przeanalizowanych uwarunkowań. Ocena ta ma więc charakter kontinuum (odzwierciedlającego również równoległe kontinuum czasowe), łączącego rozważania na temat uwarunkowanej kontekstem intencji nadawcy, z rozważaniami dotyczącymi ostatecznego efektu wyrażenia. Wynikiem oceny jest nadanie wyrażeniu (1) odpowiedniej etykiety teoretycznej, tj. określenie (1) danym aktem mowy.

Oto jak może w praktyce przebiegać analiza (1). Skoro wykładowca bywał dotąd 'liberalny' w stosunku do studentów, a treść (1) na to nie wskazuje, należy przyjąć, że wypowiedzenie (1) zostało sprowokowane konkretnym zdarzeniem i - w świetle danych kontekstowych - za takie trzeba uznać pojawienie się studentów na wykładzie z 20-minutowym opóźnieniem. W myśl tego rozumowania (które samo w sobie ma charakter inferencji niemal identycznej z inferencjami implikatur, wyprowadzanych z łamania maksymy relewancji - (1) jest jawnie nierelewantne w stosunku do oczekiwań dyskursywnych) należy dalej przyjąć, że (1) zawiera znaczący ładunek emocjonalny - co zresztą potwierdza zwrot 'na ty' - który określa status deiktyczny takich elementów, jak 'Wy' i 'każdy'. Analityk ma prawo postulować, że nadawca nie przyjmuje 'słabszego' odniesienia (szczególnie jeśli chodzi o 'każdy'), w stosunku do adresata ogólnego, lecz 'mocniejsze' - ukierunkowane na tych konkretnych studentów, którzy się spóźnili. Oczywiście nie sposób wykluczyć wielce prawdopodobnej intencji nadawcy w postaci dania przykładu ogólnemu odbiorcy poprzez napiętnowanie odbiorcy konkretnego, ale to tylko potwierdza związek pomiędzy analizą relacji deiktycznych i implikatury. W taką analizę wplatają się również rozważania na 
temat presupozycji. Nadawca może zakładać, że wyrażenie (1) osiagnie efekt dyscyplinujący, ponieważ dotąd nie posuwał się do przekazywania tak radykalnych treści, mimo posiadania powodów. Wprowadza on zatem do dyskursu na linii wykładowca-student element emfatyczny, o prawdopodobnie znacznym stopniu oddziaływania na adresata. W sumie więc analityk ma prawo przyjąć, że (1) wyraża (pośredni) akt mowy n a p o m n i e n i a (etykieta 'ostrzeżenia' nie korelowałaby jednak z wcześniejszymi liberalnymi praktykami wykładowcy). Etykieta 'napomnienia' została nadana w wyniku analizy (jedynie pokrótce tu zademonstrowanej), obejmującej rozważania na linii intencja-efekt, odnoszące się do obszarów pojęciowych deiksy, presupozycji i implikatury.

Oczywiście modyfikacja praktycznie którejkolwiek z danych (a)-(f) doprowadziłaby do przyporządkowania wyrażeniu (1) innej funkcji - mniej lub bardziej pokrewnej z funkcją napomnienia. Gdyby sytuacja opisana w (e) miała miejsce po raz kolejny, analityk otrzymałby bodziec do zastanowienia się, czy nie lepszym określeniem funkcji byłoby 'ostrzeżenie'. Modyfikacja funkcji czy też postulowanego typu aktu mowy mogłaby zaistnieć również w wyniku zastosowania przez analityka posiadanej wiedzy własnej na temat, przykładowo, odczuć wykładowcy związanych z miernym stopniem zainteresowania studentów wykładami. Odczucia określane mianem 'frustracji' sprzyjałyby zapewne przyjęciu optyki 'napomnienia', zaś odczucia bardziej radykalne, gniewu, itp., sprzyjałyby określeniu funkcji jako 'ostrzeżenia'. Tego typu zmiany w obrębie danych kontekstualnych oraz wiedzy własnej analityka w niczym nie zmieniają samego procesu analizy w kontekście interakcji pojęciowej deiksy, presupozycji czy implikatury. Wszystkie te pojęcia byłyby nadal zaangażowane, składnikowo, w indukcyjny proces wygenerowania kategorii nadrzędnej opisu, tj. aktu mowy przekazywanego w wyrażeniu.

Postulat nadrzędności (teoretycznej i metodologicznej) aktu mowy w stosunku do deiksy, presupozycji i implikatury wydaje się również wynikać ze stosunkowo prostej obserwacji, dotyczącej zakresu objaśniającego i hierarchiczności pojęć pragmatycznych - pojedynczy akt mowy może być 'realizowany' lub 'generowany' poprzez analizę sieci relacji zawierającej $n$ elementów deiktycznych, $n$ presupozycji, $n$ implikatur itd. W (1) mamy do czynienia z trzema elementami deiktycznymi, tj. 'Wy', 'każdy', 'te', licznymi założeniami przez nadawcę wiedzy wspólnej dla nadawcy i adresata (liberalne zachowania nauczyciela, mała popularność zajęć, formalny charakter zajęć (wykład) i wiele innych założeń warunkujących wypowiedzenie) oraz - mimo wszystko - różnymi możliwościami interpretowania stopnia radykalności (i konsekwencji) wypowiedzenia. Jednak wszystkie te elementy pełnią dla analityka rolę równoprawnych, składnikowych wskazówek co do tego, jaki akt mowy ma w istocie miejsce i jaka pojedyncza etykieta opisowa byłaby dla niego najodpowiedniejsza. 
Załóżmy więc, że (1) zostało ocenione jako akt napomnienia, jednak wyobraźmy sobie również, że wykładowca nie uznaje (1) za wystarczające dla osiągnięcia celu (czyli zdyscyplinowania studentów) i jest zmuszony sięgnąć, ciagle w trakcie tego samego wykładu, po dodatkowe środki językowe, które ów cel w jego rozumieniu ostatecznie zapewnią. Przyjmijmy zatem, że, w pewnych odstępach czasowych (np. pięciominutowych), już po wypowiedzeniu (1), wykładowca stosuje następujące dwa wyrażenia:

(2) Większość moich Kolegów oblewa studentów za nieobecności na wykładach.

(3) Przyrzekam Wam, że zacznę brać przykład z dr Kowalskiego i będę sprawdzać listę ${ }^{2}$.

Zauważmy, że choć (1), (2) i (3) sprzyjają osiągnięciu tego samego dalekosiężnego celu (zdyscyplinowaniu studentów), (2) i (3) kontrybuują do niego, opierając się na innych aktach mowy niż akt dyrektywny (napomnienie) zawarty w (1). Z typologicznego punktu widzenia, (2) wyraża akt asercji, zaś (3) wyraża akt zobowiązania (commissive). Problem polega na tym, że c e 1 można definiować zarówno na poziomie pojedynczego aktu mowy, w kontekście relacji intencja - efekt, jak i na poziomie wyższym i rozleglejszym czasowo. Mówiąc zatem o celu zdyscyplinowania studentów, obracamy się jednocześnie w kontekście aktu mowy napomnienia działającego stosunkowo doraźnie, jak i w kontekście tegoż samego aktu mowy (napomnienia), lecz o działaniu znacznie bardziej dalekosiężnym i potencjalnie podlegającym wspomożeniu

${ }^{2}$ Praktyka dociekań pragmatycznych pokazuje (por. uwagi metodologiczne dotyczące ewolucji badań nad pragmatyką językową w ostatnich dekadach, w: Sbisà 2009), że (dzisiejszy) językoznawca-pragmatyk $\mathrm{z}$ reguły wyraża większe zainteresowanie rozbudową analizy aktu mowy o studium innych, 'pokrewnych' aktów mowy, kontrybuujących do realizacji intencji zbiorczej, niż weryfikacją analizy pierwotnej. Innymi słowy, analityk, badający funkcję (1), chętniej pozyska dowody trafności swoich spostrzeżeń, poprzez ulokowanie (1) w koherentnej sekwencji (1)-(2)-(3) potwierdzającej funkcję (1), określoną oryginalnie w analizie pojedynczego wyrażenia, niż zawróci na szczebel tegoż wyrażenia, by jeszcze raz ocenić zakres, poprawność wyboru oraz sposób wykorzystania danych kontekstowych (a)-(f). Indukcyjny determinizm analizy pragmatycznej powoduje, że szczegółowe badania poziomu mikro stają się mitem. Zaryzykowałbym twierdzenie, że 'winę' za ten stan rzeczy ponosi panująca jeszcze stosunkowo niedawno fascynacja pracami, dotyczącymi makrostruktur tekstowych/dyskursywnych Teuna A. van Dijka, do których odniosę się w dalszej części niniejszego tekstu. Nim to nastąpi, zauważmy jednak, że taki stan rzeczy nie musi trwać wiecznie i już w chwili obecnej liczne prace z obszaru pragmatyki eksperymentalnej (por. Garrett, Harnish 2009) (a także np. pragmatyki klinicznej, por. Cummings 2009) kierują uwagę badaczy ponownie w kierunku poziomu 'mikro', zbywając klasyczne podejścia makrostrukturalne mianem armchair philosophy (dosł. 'filozofia fotelowa', dociekania o śladowym pierwiastku empirycznym). 
przez inne akty mowy (asercja, zobowiązanie, które de facto jest groźba). Rozgraniczenie między efektem aktu mowy (nawet o jednolitej etykiecie, takiej jak np. napomnienie) w kontekście 'doraźnym' i 'dalekosiężnym' jest niemożliwe. Akt mowy może spełniać funkcję porządkującą w stosunku do pojęć składnikowych, jednak jego orientacja przeciwna - tj. stopień wkładu w realizację intencji globalnych - jest trudna do uchwycenia. Efekt zdyscyplinowania studentów może być powiązany z pojedynczym aktem lub też z serią aktów mowy; nie sposób określić ile pojedynczych aktów mowy (takich jak (2) lub (3)) mogłoby się 'dokleić' do aktu wyjściowego na rzecz realizacji intencji nadawcy w dłuższej perspektywie czasowej. Przyjrzyjmy się zatem w dalszej części niniejszego tekstu relacji pomiędzy pojedynczym aktem mowy a serią aktów, podporządkowanych temu samemu dalekosiężnemu celowi.

\section{Dyskusja: poziom makropragmatyczny (dyskursu)}

W prezentowanych rozważaniach wiernie nawiązuję do moich własnych praktyk akademickich, które po części odzwierciedlają zachowanie wykładowcy - autora wyrażeń (1), (2), (3). Rzadko kiedy zaczynam seminarium od sprawdzenia listy obecności. Zamiast tego, często pytam:

(4) Witam, jesteśmy wszyscy?

tworząc tym samym dwa akty mowy bezpośrednie (przywitania i zapytania), a także pośredni akt prośby o poinformowanie mnie o nieobecnych. Akty te wykorzystują elementy deiktyczne (np. 'wszyscy'), tworzone są na podstawie określonych presupozycji (np. założenie, że nie wszyscy studenci mogą być obecni w tym momencie na zajęciach), zaś pośredni akt prośby niejako zmusza adresata do przeprowadzenia procesu inferencji. Można przyjąć, że tak właśnie wygląda - w pewnym uproszczeniu - analiza składnikowa aktów mowy wyrażenia (4).

Jako autor tego wyrażenia, mam jednak przywilej stwierdzenia $\mathrm{z}$ absolutną pewnością, iż jego funkcja wykracza nieraz daleko poza akt przywitania, zapytania czy prośby. (4) - lub też wyrażenia semantycznie i pragmatycznie podobne (por. 'dzień dobry, chyba już wszyscy jesteśmy, prawda?' itp.) pojawiają się $\mathrm{w}$ tej konkretnej sytuacji ( $\mathrm{tj}$. rozpoczęcia seminarium) na tyle często, że można uznać je za elementy rutynowe, podporządkowane większej (narzucałoby się 'globalnej', ale to określenie rezerwuję dla opisu makroaktu mowy) intencji. Zwróćmy uwagę na następującą analogię: jeśli codziennie rano 
wychodzę do kiosku po gazetę (co stanowi zdarzenie złożone z serii mikrozdarzeń analogicznych w swojej składnikowej funkcji w stosunku do pojedynczych aktów mowy opisanych w (4)), za moją 'większą intencję' uznać można długofalową chęć orientowania się w bieżących wydarzeniach (relacjonowanych w gazecie). Analogia ta każe nam zaakceptować popularne u teoretyków aktów mowy przekonanie o związku pojęciowym pomiędzy zdarzeniem fizycznym a aktem mowy i, co za tym idzie, szukać w (4) składników realizacji większej intencji.

Poszukiwania te prowadzą do wniosku, że 'większą intencją' determinująca (4) jest rozpoczęcie seminarium, które możliwe jest tylko po uprzednim sprawdzeniu warunków jego realizacji, powiązanego z intencją celu przeprowadzenia produktywnych zajęć. Nie jest to wielce oryginalna konkluzja, ale stanowi jasny i wygodny punkt odniesienia do rozważań na temat natury intencjonalności i sposobów jej wyrażania w języku. Już w tym momencie widzimy, że natura ta jest skomplikowana i wykracza poza kontekst pojedynczego wypowiedzenia, a zatem wymaga poszerzenia aparatu badawczego. Aparat ten miałby za zadanie opis intencjonalności na poziomie dyskursu.

Niewątpliwie łatwo wyobrazić sobie sytuację, w której wypowiedzenie (4) nie wystarcza do skutecznego rozpoczęcia seminarium i istnieje potrzeba „wsparcia” go dodatkowymi wyrażeniami. Wyrażenia te abstrahowane sa z n i e s k o ń c z o n e g o z b i o r u wyrażeń zdolnych realizować, w mniejszym lub większym stopniu, tę ('większą') intencję. Oto kilka z nich: 'Robi się późno', 'Czy mogę prosić o zamknięcie drzwi?', 'Panie Adamie, proszę o uwagę!', 'No dobrze, zatem już zaczniemy', 'Znów zabrakło pisaków do tablicy!', 'Nie pamiętam, kiedy ostatnio zaczęliśmy punktualnie' etc. Wszystkie te na pozór różne wyrażenia mogą wnosić określony wkład w realizację zasadniczej intencji. Zauważmy, że wkład ten wnoszony jest przez wypowiedzenia, zawierające formalnie różne akty mowy (asercje, dyrektywy, akty ekspresywne), o bezpośredniej lub pośredniej sile illokucyjnej. Z kolei, patrząc 'w dół' całej struktury, każdy z tych aktów może charakteryzować się osobną kompozycją składników deiktycznych, presupozycji i implikatur.

Tworzenie przez nadawcę pojedynczych aktów mowy (z których każdy charakteryzuje się odrębną kompozycją składników mikropragmatycznych), podporządkowanych intencji nadrzędnej, doczekało się anglojęzycznej etykiety speech event, którą można na język polski przetłumaczyć jako 'seryjny akt mowy'3. Seryjny akt mowy może, zgodnie z powyższą charakterystyką, rozcią-

\footnotetext{
${ }^{3}$ Tłumaczenie to, moim zdaniem, trafniej określa naturę intencjonalności złożonej, niż czyni to anglojęzyczny oryginał. Mamy wszak do czynienia nie z konkretnym 'wydarzeniem' (event), lecz serią zdarzeń odzwierciedlonych w serii aktów mowy. Wydaje się, że literatura angloję-
} 
gać się na potencjalnie nieskończoną liczbę wyrażeń, w zależności od tego, ile z nich potrzeba dla zrealizowania nadrzędnej intencji. Jeśli np. studenci mojej grupy seminaryjnej wchodzą do sali, dyskutując żywo o dopiero co zakończonym egzaminie, w którym uczestniczyli, przygotowanie warunków do rozpoczęcia seminarium może wymagać użycia stosunkowo dużej liczby wypowiedzeń. W innym wypadku wystarczy kilka krótkich uwag, najczęściej o charakterze technicznym, by przejść do meritum, tzn. rozpocząć merytoryczną część zajęć. Długość 'dyskursu wprowadzającego' jest więc warunkowana kontekstem pozajęzykowym. Należy podkreślić ponownie, że seryjny akt mowy może podporządkowywać sobie taką liczbę wyrażeń (i pojedynczych aktów mowy w nich zawartych), jaka konieczna jest dla sprostania wymaganiom kontekstu. Wyrażenia te nie muszą koniecznie układać się w strukturę monologu. Tworząc warunki do rozpoczęcia seminarium, wypowiadam nieraz kilka zdań pod rząd, robię pauzę, czasem odpowiadam na pytanie lub pytania, które pojawia się spontanicznie, a następnie powracam do monologu. Moje zachowanie jest więc typowym z a c h ow a n i e m d y s k u r s y w y m, wpasowującym się w określony kontekst interpersonalny, społeczny i reagującym elastycznie na rozwój uwarunkowań tego kontekstu ${ }^{4}$.

zyczna od dawna miała i ma kłopot z precyzyjnym nazwaniem opisywanego zjawiska i stąd pojawiają się różne propozycje. Choć szeroko cytowany Jacob Mey (1993, 2001) mówi o speech events, równie popularny Stephen Levinson (1983) przyjmuje nomenklaturę activity type ('typ działalności'?), a z kolei Peter Grundy (1995) proponuje po prostu genre (dosłownie 'rodzaj', ale chyba lepiej brzmiałoby 'gatunek' (mowy)).

${ }^{4}$ Używając pojęcia 'zachowanie dyskursywne', zwracam ponownie uwagę na równoległość pojęć 'akcji' (fizycznej) i 'aktu' (mowy). Każda akcja fizyczna wykonywana jest w kontekście zdarzeń, które zaistniały uprzednio oraz w kontekście antycypowanych zdarzeń przyszłych, na które akcja bieżąca ma wpływać. Podobnie, każdy akt mowy (a właściwie każdy przypadek użycia języka w dyskursie) jednocześnie nawiązuje do (części) dyskursu minionego oraz uaktualnia kontekst bieżący na rzecz dyskursu przyszłego. Tak jak nie sposób określić liczbę akcji pokrewnych, zdolnych z całkowitą pewnością zbudować konkretną rzeczywistość przyszłą, nie sposób również określić liczbę aktów mowy, która byłaby konieczna i wystarczająca dla realizacji konkretnej intencji zbiorczej. Relatywizm makroanalizy pragmatycznej, który podnosi niniejszy podrozdział, jest więc pochodną relatywizmu konstruowania relacji pomiędzy zdarzeniami zachodzącymi w czasoprzestrzeni. Ten ostatni dostrzegaja już m.in. Edmund Husserl (1928/1991) i Martin Heidegger (1953/1996), wskazując niemniej ciągle na nadrzędność opisu zjawisk konstruowanych (np. czasu) nad opisem zjawisk rzeczywistych. We wczesnych pracach, określanych (mniej lub bardziej precyzyjnie) przymiotnikiem 'pragmatyczne' (np. w pracach Austina i Searle'a z lat sześćdziesiątych XX wieku), odwołania do sposobu konstruowania rzeczywistości (przeszłej, bieżącej i przyszłej) jako głównego wyznacznika funkcji języka są w mojej ocenie niewystarczające (np. w typologii aktów mowy Searle'a (1969), jedynie kategoria aktów deklaratywnych wydaje się odpowiednio dopracowana względem zarówno prospektywnego, jak i retrospektywnego opisu relacji pomiędzy językiem a rzeczywistościa) i być może 
Przywołane wcześniej pojęcie nieskończoności powraca do dyskusji, jeśli ukierunkujemy ją na kwestię ewentualnego istnienia intencji 'supernadrzędnej', której podporządkowane byłyby większe grupy seryjnych aktów mowy (analogicznie do hierarchii 'akt mowy' - 'seryjny akt mowy', tylko tym razem na jeszcze wyższym (ostatecznym?) poziomie struktury intencjonalności). Intrygujące jest spostrzeżenie, że w przykładzie (4) seryjny akt mowy, który realizuje intencję rozpoczęcia seminarium, opierając się na elementach składowych (indywidualne akty mowy), sam może jawić się jako podrzędny element składowy dla osiagnięcia jeszcze szerszego i bardziej dalekosiężnego celu, np. udanego przeprowadzenia seminarium w całości. Realizacja takiego celu wiąże się z zaistnieniem potencjalnie nieskończonej liczby seryjnych aktów mowy, których intencje obejmują czas od rozpoczęcia seminarium do jego zakończenia. Przykładowymi intencjami mogą być chęć wyjaśnienia problemu merytorycznego, który wyniknął w trakcie zajęć, bądź też chęć zadania pracy domowej. Seryjne akty mowy, wyrażające te dwie intencje, mogą oczywiście, zgodnie ze swą opisaną wyżej natura, zawierać akty składowe, takie jak np., w drugim z przytoczonych przypadków, akt ekspresywny (udzielenie studentom reprymendy za niezadowalające wykonanie poprzedniego zadania domowego), akt zobowiązania (commissive; wyrażenie groźby niezaliczenia zajęć w przypadku dalszego zaniedbywania prac domowych), akt dyrektywny (polecenie wykonania nowego zadania i/lub ponownego wykonania zadania bieżącego na kolejne seminarium), akt asercji (opis treści i celu zadania) itp. Zróżnicowanie i liczba tych pojedynczych aktów mowy są nie mniejsze niż miało to miejsce w przypadku aktów składających się na seryjny akt mowy rozpoczęcia seminarium.

$\mathrm{W}$ ten sposób wszelkie dotychczasowe rozważania zaprowadziły nas, droga na wskroś indukcyjną, na szczyt swoistej 'piramidy intencjonalności'. Przychodzi nam w tym miejscu zadać pytanie o możliwość istnienia 'supernadrzędnej', 'globalnej' kategorii wyrażania intencji, konstruktu, który byłby zdolny objąć swym zakresem opisu wszystkie intencje realizowane $\mathrm{w}$ ramach składowych seryjnych aktów mowy, a więc pośrednio także wszystkie intencje realizowane w ramach aktów mowy indywidualnych. Pytanie to stawia de facto (choć nie bezpośrednio) klasyczna teoria makroaktu mowy, autorstwa Teuna A. van Dijka. Teoria ta zakłada istnienie globalnego aktu mowy, wyrażanego poprzez cały dyskurs, obejmujący sekwencje rozmaitych aktów mowy ${ }^{5}$. Jej niewątpliwą

dopiero późniejszym pracom, na styku pragmatyki i językoznawstwa kognitywnego (zob. np. teoria (bieżącej) przestrzeni dyskursu Ronalda Langackera (2001)), zawdzięczamy narzędzia pojęciowe, umożliwiające krytyczną ocenę względności makroanalizy funkcji języka.

5 Por. van Dijk (1977, 1980), a także van Dijk, Kintsch (1983). 
zaletą jest stosunkowo udana próba systematyzacji podejścia do seryjnych aktów mowy jako komponentów pewnego globalnego 'makroaktu'. Jednak już samo doprecyzowanie pojęcia tegoż makroaktu nastręcza trudności i wykazuje nieuchronną względność oceny, czym właściwie jest ów 'cały dyskurs' i jakie są jego granice. Czy zatem przypadek (4) odnosimy np. do wszelkich zachowań dyskursywnych $\mathrm{w}$ ramach czasowych trwania tego konkretnego seminarium? Jeśli tak, to ta dana relacja hierarchiczna $\mathrm{makroakt}-\mathrm{ser} \mathrm{y} \mathrm{j} \mathrm{e} \mathrm{a} \mathrm{k} \mathrm{t} \mathrm{y}$ mowy - (indywidualne) akty mowy wygląda sama w sobie logicznie, a jej aparat opisu wydaje się metodologicznie poprawny. Relacja ta ignoruje jednak oczywisty potencjał postulowanego makroaktu (wyrażającego intencje przeprowadzenia udanego seminarium) łączenia się z ... kolejnymi makroaktami, na rzecz wyrażenia jeszcze 'rozleglejszej', jeszcze 'bardziej nadrzędnej' intencji. Intencja przeprowadzenia udanego seminarium może być przecież częścią składową intencji sprawnego przeprowadzenia całego semestralnego kursu, co z kolei wpisuje się w intencję odpowiedniego wykonywania wszystkich obowiązków akademickich itd. Równolegle akumulują się kolejne, coraz rozleglejsze makroakty mowy, wyrażające owe intencje. Ustalenie 'supernadrzędnej' intencji, wyrażonej w ramach 'supernadrzędnego' makroaktu mowy wydaje się w tej sytuacji przedsięwzięciem nie tyleż nawet filozoficznym, co po prostu niemożliwym do wykonania.

Nie znaczy to jednak, że należy lekceważyć te próby, uznając teorie w typie modelu makroaktu mowy van Dijka za kompletnie pozbawione wartości poznawczej. Niewątpliwą, choć nieco paradoksalną, zaletą poszukiwań ściśle zdefiniowanych poziomów w hierarchii wyrażania intencjonalności w języku jest moim zdaniem wykazanie ograniczeń takich przedsięwzięć oraz - w konsekwencji - skierowanie uwagi analityków na bardziej wymierzalne aspekty i wyraźniej wytyczone terytoria użycia języka niż 'cały dyskurs'. Od co najmniej dwóch dekad jesteśmy świadkami rozkwitu analizy konwersacyjnej (Conversation Analysis; CA), która istotnie - co podnoszą krytycy ${ }^{6}$ - operuje w obrębie ograniczonych kontekstów pozajęzykowych, jednakże wykształciła szereg cennych pojęć, które przeniknęły już nie tylko do aparatu pragmatyki językowej, ale wręcz językoznawstwa w ogóle. Mam tu na myśli choćby 'miejsce przekazania głosu' (transition relevance place) czy też 'pary przyległe' (adjacency pairs), terminy wykorzystywane często również w socjolingwistyce czy lingwistyce stosowanej. Poza tym, już samo postawienie pytania o intencję 'nadrzędną' czy 'globalną' jest metodologicznie cenne, ponieważ zmusza analityka do rozważań, dotyczących wyrażania intencjonalności w obrębie

\footnotetext{
${ }^{6}$ Zob. przegląd prac Harveya Sacksa, Emanuela A. Schegloffa, Gail Jefferson, Jonathana Pottera i wielu innych, a także ich krytykę, w: Ten Have (2007).
} 
dłuższego okresu. Pochodną takiego podejścia mogą być (i sa) modele 'kompensacyjne', tzn. zajmujące się kwestią utrzymywania realizacji danej intencji w rozległym okresie, w którym pewne składniki wyrażania intencji naturalnie wymierają i muszą być zastąpione innymi składnikami. Modele te szczególnie często budowane są w dziedzinie tzw. krytycznej analizy dyskursu (Critical Discourse Analysis), a ich przykładem mogą być teoria modalności dyskursu Paula Chiltona (2004) lub też model legitymizacji dyskursu politycznego (Cap 2008).

\section{Uwagi końcowe}

W niniejszym tekście starałem się zwrócić uwagę na swoisty paradoks analizy pragmatycznej. $Z$ jednej strony analiza ta podlega determinizmowi indukcyjnemu, który powoduje stopniowe odwrócenie uwagi językoznawcy od studiów poziomu 'mikro'. W pogoni za dowodami twierdzeń pierwotnych, które miałyby być dostępne na poziomie dyskursu, językoznawca nadaje analizie pęd, który powoduje, iż dokładniejsze dociekania poziomu pojedynczego wyrażenia stają się mitem. $Z$ drugiej strony analiza pragmatyczna, która zawędrowała na poziom 'makro' nie jest w stanie wygenerować wniosków, które oparłyby się zarzutowi względności.

Paradoks, który naszkicowałem, wydaje się wynikać z niejednoznacznego statusu aktu mowy jako kategorii porządkującej w analizie pragmatycznej. Kategoria ta sprawdza się na poziomie indywidualnego wypowiedzenia oraz przy orientacji analizy ' $w$ dół', tj. dla wyszczególnienia częściowo zleksykalizowanych elementów składowych (zob. deiksa, presupozycja semantyczna, implikatura konwencjonalna itp.) wyrażania intencji w tymże wypowiedzeniu. Oczywiście na określenie 'sprawdza się' należałoby nałożyć następujący warunek: 'tak długo jak analityk chce/umie ją wykorzystywać w ten konkretny sposób' - czyli na poziomie 'mikro'. Kategoria aktu mowy zawodzi jednak przy orientacji analizy 'do góry', kiedy od poziomu pojedynczego wyrażenia przechodzimy na poziom serii powiązanych ze sobą kontekstowo wyrażeń, czyli dyskursu. Analiza aktu mowy na poziomie dyskursu wiąże się $\mathrm{z}$ nieuchronną relatywizacją zakresu intencji wyrażanej tym aktem, co stanowi zasadniczą przyczynę niepowodzenia.

$\mathrm{Na}$ koniec chciałbym postawić pytanie o ewentualną konstruktywność tego niepowodzenia. Nadmieniłem już wcześniej, że uzmysłowienie sobie relatywizmu wniosków wygenerowanych na poziomie 'makro' może skutkować skierowaniem uwagi analityka na bardziej wymierzalne aspekty i wyraźniej 
wygraniczone terytoria użycia języka. Nie sposób więc wykluczyć powrotu analityka na poziom 'mikro', w poszukiwaniu dalszych obserwacji na szczeblu wyrażenia, które łagodziłyby późniejszą względność wniosków po dotarciu analizy na szczebel dyskursu. Oczywiście łatwo zauważyć, że potencjał tej praktyki jest nieograniczony, wzajemne oddziaływanie na siebie teorii ogólnej i obserwacji szczegółowej może mieć charakter cykliczny/ciagły. Tak więc, jeśli nie można w pełni zobiektywizować analizy pragmatycznej na poziomie dyskursu, być może należy zadowolić się strategią typu 'im więcej [obserwacji i dowodów], tym lepiej', tak jak uczynili to choćby językoznawcy funkcjonalni (np. szkoła Systemic Functional Linguistics Hallidaya, por. np. Halliday 1994) czy też krytyczni analitycy dyskursu (por. np. Faiclough 2003; Wodak, Chilton 2005). Obie te szkoły (a także inni współcześni analitycy dyskursu - ostatnio np. ci zaangażowani w analizę g a t u n k ó w (genres)) bronią się - z zadziwiającą skutecznością - przed zarzutami o nieprecyzyjność opisu, podnosząc logiczny w sumie argument, że opis dyskursu podlega takim samym prawom jak sam dyskurs, tj. niekończącej się ewolucji, dynamiki i interakcji biegunów teorii i empirii.

\section{Bibliografia}

Austin, J. 1962. How to Do Things with Words, Oxford: Oxford University Press.

Cap, P. 2008. „Towards the proximization model of the analysis of legitimization in political discourse", Journal of Pragmatics 40, 17-41.

Chilton, P. 2004. Analysing Political Discourse: Theory and Practice, London: Routledge. Cummings, L. 2009. Clinical Pragmatics, Cambridge: Cambridge University Press.

Dijk, T. van. 1977. Text and Context, London: Longman.

Dijk, T. van. 1980. Macrostructures. An Interdisciplinary Study of Global Structures in Discourse, Interaction, and Cognition, Hillsdale, NJ: Erlbaum.

Dijk, T. A. van, Kintsch, W. 1983. Strategies of Discourse Comprehension, New York: Academic Press.

Fairclough, N. 2003. Analyzing Discourse. Textual Analysis for Social Research, London: Routledge.

Garrett, M., Harnish, R. M. 2009. „Q-phenomena, I-phenomena and impliciture: some experimental pragmatics", International Review of Pragmatics 1, 84-117.

Grundy, P. 1995. Doing Pragmatics, London: Edward Arnold.

Halliday, M. A. K. 1994. An Introduction to Functional Grammar, $2^{\text {nd }}$ ed., London: Edward Arnold.

Heidegger, M. [1953] 1996. Being and Time, Albany, NY: SUNY Press.

Horn, L., Ward, G. 2004. The Handbook of Pragmatics, Oxford: Blackwell. 
Howarth, D. 2000. Discourse, Philadelphia: Open University Press.

Huang, Y. 2007. Pragmatics, Oxford: Oxford University Press.

Husserl, E. [1928] 1991. On the Phenomenology of Consciousness of Internal Time, Dordrecht: Kluwer.

Kalisz, R. 2006. „Językoznawstwo kognitywne w analizie pragmatyki językowej”, [w:] P. Stalmaszczyk (red.), 234-250.

Kubiński, W., Stanulewicz, D. (red.), 2001. Językoznawstwo kognitywne II: zjawiska pragmatyczne, Gdańsk: Wydawnictwo UG.

Langacker, R. W. 2001. „Discourse in cognitive grammar”, Cognitive Linguistics 12, 143-188.

Levinson, S. 1983. Pragmatics, Cambridge: Cambridge University Press.

Mey, J. 1993. Pragmatics, Oxford: Blackwell.

Mey, J. 2001. Pragmatics, $2^{\text {nd }}$ ed., Oxford: Blackwell.

Post, M. 2001. „Efekty i akty perlokucyjne”, [w:] W. Kubiński, D. Stanulewicz (red.), $135-147$.

Sbisà, M. 2009. „Speech act theory”, [w:] J. Verschueren, J.-O. Ostman (red.), 229-243.

Searle, J. 1975. „A taxonomy of speech acts”, Minnesota Studies in the Philosophy of Science 9, 344-369.

Stalmaszczyk, P. (red.), 2006. Metodologie językoznawstwa: podstawy teoretyczne, Łódź: Wydawnictwo UŁ.

Ten Have, P. 2007. Doing Conversation Analysis. A Practical Guide, Thousand Oaks, CA: Sage.

Tsohatzidis, S. (red.), 1994. Foundations of Speech Act Theory: Philosophical and Linguistic Perspectives, London: Routledge.

Verschueren, J., Ostman, J.-O. (red.), 2009. Key Notions for Pragmatics, Amsterdam: John Benjamins.

Wodak, R., Chilton, P. 2005. A New Agenda in (Critical) Discourse Analysis, Amsterdam: John Benjamins. 